\title{
Journalist of Print Mass Media in Medan Study: Journalism, Print Media of Newspaper Journalistic and Organizational Structure of Print Media
}

\author{
M. Yoserizal Saragih \\ State Islamic University of North Sumatera, Medan, Indonesia \\ Email: yosesaragih77@gmail.com
}

\begin{abstract}
:
The aim of this study is to determine the journalist of print mass media in Medan. This study is about journalism, print media of newspaper journalistic and organizational structure of print media. The work area of journalists in Medan is public space, an area that is worthy of being known by the public or the public. Therefore, journalists are required to have the ability to reveal and inform a complete problem by upholding the values of truth and justice and must be able to make themselves half diplomats, half detectives. This means that journalists must have skilled diplomacy skills, even though the way they work is similar to detectives. Mass media journalism is a tool used to convey messages from sources to the public using mechanical communication tools, such as newspapers, radio, television, films and so on. And in this case the mass media being referred to is print mass media. That newspapers are sheets published by the press which contain news, essays, writings, advertisements, and other journalistic products that are printed periodically, circulated, and sold in general, which function as social control tools that provide information both entertainment education and another thing for the community.
\end{abstract}

Keywords :

journalist; print mass media; newspaper; organizational structure of print media.

\section{Introduction}

The mass media can be said to be a vehicle for delivering journalistic work. Mass media is a term used by the public in referencing the place where news is published. The journalistic work of journalists is published through the mass media. Any news in journalism becomes meaningless without being supported or published through the media. So, the mass media is a place to deliver news.

Submitting journalist information in the form of news requires a communication channel called the media. The term mass media because it refers to the use of public reading. The mass media provides information about change, how it works and the results achieved or will be achieved. The main function of mass media is to provide information on widespread interest and to advertise products.

\section{Review of Literature}

\subsection{Definition of Journalists}

Journalist is a person who works in journalism and journalistic tasks routinely or in other definitions, journalist can be said as a person whose job is to find and compile news to be published in the mass media, both print media, electronic media and online media. The profession of news hunters is called a journalist or many of its terms, such as news journalistss, journalistss, newsgatherer, press-man, mass communicators, press mosquitoes, ink coolies and defenders of people's interests. In terms of terms, journalists are people whose job is to find news. Then the news is processed and arranged to be sent to the editorial desk which will be published to the public. 
In Law No. 1 of 1996 Article 1 and 3 also clearly stated that: "Journalism is work / activity / business related to the collection, processing and broadcasting in the form of facts, opinions, reviews, pictures and so forth for companies, radios, television and movies". Whereas in the narrow sense, journalism can be understood as activities related to writing for the media of mass communication.

In this sense, for example, the term new journalism. Journalism here does not mean new journalism, but what is meant is a new form of writing for mass communication media. The press world in Indonesia itself is quite overwhelmed to deal with a number of deviations from the profession of someone who claims to claim himself as a journalist. ${ }^{1}$ If seen further, the quality of journalists' news is strongly influenced by the status of journalism in question in their media institutions. In a simple context journalists can be categorized into three types, namely:

1. Professional Journalist

2. Freelance Journalist

3. Amateur Journalist

Professional journalists are respected by the public. Because journalists are considered critical and sharp in asking questions, able to disclose information in detail, are skilled at covering news and able to influence others through their writing. Journalists are very identical with journalistic activities. In Press Law No. 40 of 1990, Chapter I Article 1 stated that journalists are people who regularly carry out journalistic activities.

The journalist profession has high mobility and dynamics. Journalists not dealing with inanimate objects or the imaginary world. Journalists must actively make "personal contact" or relationships with others. Interestingly, journalists have relationships with all people and various backgrounds and social status. However, journalists must continue to uphold the social status of others, especially the speakers because the news sources who become journalists' partners are people who have feelings, have emotions, and may have various ranks and fates.

Journalists must be good at getting along with all levels of society. A person's ethnicity, religion, race and customs / area are not important in the eyes of journalists. Journalists work more on "ratio" than "emotion". Journalists must also be known as neutral and "level-headed", but still do not lose the critical power and intelligence of investigations in carrying out their duties. In carrying out their duties a journalist must have a strong mentality.

According to Saragih (2018) Journalistic as a method in a very strategic propaganda .Beside it can be enjoyed by many people, the product of journalism also can be more lasting or durable, because it can be stored or read anytime.

Journalists can be regarded as the "spirit" of journalism or the press. Journalists become the key players in journalistic activities. Journalistic dependence on journalists is very high. Without journalists, even journalism is lame. Like there but nothing. Because in journalism, journalists are looking for and collecting news. Even journalists write news. The quality of the reporting of a media agency also depends very much on the expertise and skills of its journalists.

In the future, the journalist profession will continue to develop. Journalists and journalistic activities are needed and important for the community. Therefore, to work and pursue the profession of journalists it is not enough to rely solely on passion and enthusiasm.

${ }^{1}$ Yunus, Syarifuddin. Jurnalistik Terapan. Bogor. Ghalia Indonesia, 2010. 
Being a journalist is a long process. Provision of education is very necessary for journalists. Provision of mental readiness and courage is also needed in pursuing the profession as a journalist. In essence, to become a journalist requires practical and theoretical abilities. There are no qualified journalists born instantly. Professional journalists need a strong personal background in addition to being required by professionalism in carrying out their journalistic duties. Only professional journalists can ultimately ensure the establishment of a journalistic code of ethics as a foothold of journalistic duties.

Working as a journalist has its own prestige, even some people consider the profession as a journalist to have high prestige. Professional journalists are considered to have a "class" that is different from other professions. Apart from the welfare aspect, working as a journalist has a relatively higher image compared to other professions. This is because the journalist profession is considered a profession in which to combine the power of knowledge and skills.

The work area of a journalist is a public space, an area worthy of being known by the public or the public. Therefore, journalists are required to have the ability to reveal and inform a complete problem by upholding the values of truth and justice.

Regarding the journalist's job, James Gordon Bennet, founder of The New York Herald, stated that the journalist's job is half diplomat, half detective. ${ }^{2}$ This means that journalists must have skilled diplomacy skills, even though the way they work is similar to detectives.

Some journalists' tasks that deserve attention in carrying out journalistic tasks, include:

a) Summing up the facts

b) Processing the facts

c) Present the facts

Based on the journalist's duties, the journalists is deemed to have carried out his duty if he has presented news and events that fulfill the above tasks.

On the other hand, Cart Warren in the book Modern News Reporting emphasizes the need for journalists to have ten principles to carry out their duties, namely ${ }^{3}$ :

a) Able to pay attention and listen

b) Has wide range of relationships

c) Having knowledge

d) Diligent in reading and critical

e) Have the initiative and be able

f) Work hard and be patient

g) Using the mind, not fake

h) Writing, writing and writing

i) Think clearly and precisely

j) Able to use time

With these principles, in the end journalists are expected to achieve specialization in journalistic work. Specialization in the field of journalism is needed as an important element in building professionalism of journalists. Journalists are required to have knowledge of the material in their areas of coverage. Even though skilled reporting applies to all areas of more specific

\footnotetext{
2 Yunus, Syarifuddin. Jurnalistik Terapan. Bogor. Ghalia Indonesia, 2010.

${ }^{3}$ Yunus, Syarifuddin. Jurnalistik Terapan. Bogor. Ghalia Indonesia, 2010.
} 
coverage. News that is objective, accurate and reliable is basically only born from the work of journalists who understand the ins and outs of the field of coverage, such as the fields of crime, economics, law, religion, politics, and sports and so on. This also becomes a reference in determining the mechanism of action of a media editor, in addition to helping determine the rubric composition and content of the news presented by the mass media.

\subsection{Definition of Mass Media}

According to Cangara, mass media is a tool used to convey messages from sources to the public by using mechanical communication tools, such as newspapers, radio, television, films and so on. ${ }^{4}$ And in this case the mass media being referred to is print mass media.

According to Cangara said that the media is a means of communication, so that mass communication is inseparable from mass media. ${ }^{5}$ Mass media is used to show the application of a technical tool (media) that channels or is a container of mass communication.

Meanwhile, according to Bitter, mass media is a means of transmitting information, newspapers, magazines, books, films, radio, and television or a combination of forms of these media forms. ${ }^{6}$ According to Muhtadi there are five things that indicate the nature of the mass media, namely ${ }^{7}$ :

1. Institutional

2. One-Way

3. Expanding and in unison

4. Using technical or mechanical equipment

5. Be Open namely ${ }^{8}:$

According to Avery and Sanford revealed there are three functions of the mass media,

1. The surveillance of the environment, which is observing the environment

2. The correlation of the part of society in responding to the environment, which is to correlate the information data obtained with the needs of the target audience, because the communicator places more emphasis on evaluation selection and interpretation.

3. The transmission of the social heritage from one generation to the next, the intention is to channel cultural values from one generation to the next.

The three functions above basically provide an assessment of the mass media as a tool or means that is sociologically an intermediary to connect or convey certain values to the community and these three things become an obligation that needs to be done by the mass media in general. While Mc. Quail put forward the important functions of mass media, as follows?:

1. Media is a changing and developing production that creates jobs, goods and services and enlivens other related industries.

2. Mass media is a source of strength as a means of control, management and information tools of the community that can be utilized as a substitute for power or other sources.

3. The media is a location (forum) that is increasingly developing, to display events of community life both nationally and internationally.

\footnotetext{
${ }^{4}$ Canggara, Hafied. Dimensi Komunikasi. Jakarta. Rajagrafindo Persada, 2003.

${ }^{5}$ Canggara, Hafied. Dimensi Komunikasi. Jakarta. Rajagrafindo Persada, 2003.

${ }^{6}$ Muhtadi, Asep. Komunikasi Jurnalistik. Jakarta. Grassindo, 2003.

${ }^{7}$ Muhtadi, Asep. Komunikasi Jurnalistik. Jakarta. Grassindo, 2003.

${ }^{8}$ Kuswandi, Wawan. Komunikasi Massa Sebuah Analisis Media Televisi. Jakarta. Rineka Cipta, 2002.

${ }^{9}$ Mc.Quail, Dennis. Teori Komunikasi Massa, Jakarta. Rajagrafindo Persada, 1994.
} 
4. The media often acts as a vehicle for the development of life, not only in terms of developing procedures, modes and symbols, but also in terms of developing procedures, modes and symbols, but also in the development of lifestyles and norms.

Steven H. Chaffee said there are five effects of mass media as physical objects, namely ${ }^{10}$ :

1. Economic effects

2. Social effects

3. Effects on scheduling activities

4. Effects on the channeling / elimination of certain feelings

5. Effects on people's feelings towards the media

\section{Discussion}

In the beginning, newspaper journalism was often identified with the press, but because of the broad understanding of the press, where electronic media are now categorized with the media as well. For this reason, in a narrow sense, the press only covers print media, one of which is the newspaper.

The development of newspapers as print media occurred in 1833 with the birth of the New York Sun newspaper as one of the first newspapers and until now the newspaper is still produced in various countries. The definition of a newspaper in the Indonesian Press Encyclopedia book is: "The term for press publishers in the printed mass media, in the form of news sheets, advertisements and published periodically, can be daily, weekly, monthly, and generally distributed. ${ }^{11}$ The contents must be actual, they must also be universal, meaning that the news must be related to people from groups and groups".

Then say that the newspaper may be said to be the oldest mass media before the discovery of film, radio, and television. ${ }^{12}$ Newspapers have limitations because they can only be enjoyed by those who are literate, and are more liked by adults. From the above understanding, we can see that newspapers are sheets published by the press which contain news, essays, writings, advertisements, and other journalistic products that are printed periodically, circulated, and sold in general, which function as social control tools that provide information both entertainment education and other matters for the community. Then Meinanda said that the newspaper must also meet several requirements, according to Karl Bascwhite to be called a newspaper, namely ${ }^{13}$ :

1. Publicity

2. Periodicity

3. Universality

4. Actuality

5. Continuity

If judging from the aspect of its mission, newspapers are classified into four sections by Albert F. Henning, namely ${ }^{14}$ :

1. General Newspaper

2. Special Newspaper

3. Newspapers that are published depend

${ }^{10}$ Canggara, Hafied. Dimensi Komunikasi. Jakarta. Rajagrafindo Persada, 2003.

11 Junaedhie, Kurniawan. Ensklopedi Pers Indonesia. Jakarta. Gramedia Pustaka Utama, 2001.

${ }^{12}$ Canggara, Hafied. Dimensi Komunikasi. Jakarta. Rajagrafindo Persada, 2003.

${ }^{13}$ Meinanda, Teguh. Komunikasi dan Jurnalistik. Bandung. Armico, 2001.

${ }^{14}$ Meinanda, Teguh. Komunikasi dan Jurnalistik. Bandung. Armico, 2001. 


\section{Small Newspapers (Tabloids)}

Based on this opinion, talking about newspapers in Medan will not be separated from the news context as their contents. As a presenter of information (news or messages), newspapers get enough attention from the public. Its regularly published nature, especially the daily newspapers, has always been a daily situational development that provides the latest and fresh (actual) information. Another plus, because it is printed so that it can always be read repeatedly if deemed necessary, and can also be used as practical reference material. These advantages are special defenders of newspapers with other types of media (especially electronic media).

The term of organization and organizational structure are often heard wherever we are. Both the environment around the house, print media, electronic media and when we are in colleague. The word organization itself comes from the language of organ on which in Greek means tool. The organization is a means of cooperation used by several people who have the same vision and mission in order to achieve the same goals.

There are two major parts to a press publication or mass media. The editorial department and the marketing department or the business department. The editorial section is led by the chief editor. The marketing department is led by marketing managers or business leaders. Above both are general manager. There is also a General Manager who is also the Chief Editor. ${ }^{15}$

The Editorial Section's job is covering, compiling, writing, or presenting information in the form of news, opinion, or features. The people are called journalists. Editor is the ideal side of a media or press publication that carries out the vision, mission, or idealism of the media.

The Editorial Section is headed by an Editor in Chief. Under the Editor in Chief there is usually a Deputy Editor in Chief. The Chief Editor / Deputy Editor in Chief supervises a Managing Editor who coordinates the Editor, Journalists Coordinator or Coverage Coordinator (if needed), Journalists and Photographers, Correspondents and Contributors. The contributors included freelancers (articles) and columns. In the editorial section there is also what is called the Editorial Board or Editor's Advisor. Usually consists of Chief Editor, Deputy Chief Editor, Redpel, Business Leaders and people chosen to be advisors in the editorial field.

There is also what is called an Expert Staff or Expert Editor, namely people who have expertise in certain scientific fields whose editorial opinions are urgently needed for news analysis purposes. Other parts related to the editorial field are the Preprint Editor in charge of Graphic Design (Setting, Lay Out, and Artistic) tasks as well as the Library and Documentation. In certain cases, the Research and Development (R\&D) section can enter the Editorial Section.

If viewed in terms of organizational structure, the positions contained in the media editor can be described as follows ${ }^{16}$ :

1. General Manager

$\mathrm{He} / \mathrm{she}$ is responsible for the entire running of the press, both inside and outside. $\mathrm{He} / \mathrm{she}$ can delegate accountability to the law to the Editor in Chief as long as it concerns the content of the publication (editorial) and to the Business Leader as long as it concerns the issuance of the issue.

\footnotetext{
15 http://tonz94.wordpress.com/2009/05/02/mnajemen-media-massa

${ }^{16}$ Yunus, Syarifuddin. Jurnalistik Terapan. Bogor. Ghalia Indonesia, 2010.
} 
2. Editor in Chief

Editor in Chief is responsible for the mechanism and activities of daily editors' work. $\mathrm{He} / \mathrm{she}$ must oversee the contents of all the mass media rubrics he/she leads. In any newspaper, the Chief Editor sets policies and oversees all editorial activities. He/she acts as a general or commander whose orders or policies must be obeyed by his subordinates. That authority belongs to him must be held responsible if the media reporting is sued by another party.

The Editor in Chief is also responsible for writing and editorial content which is the Editor's opinion (Desk opinion). If the Chief Editor is unable to write it, it is also common for the editorial editor, one of the members of the editorial board, one of the editors, even a journalists or anyone with the permission and knowledge of the Chief Editor who is able to write it by voicing his newspaper's opinion about an actual problem.

\section{Editorial Board}

The Editorial Board usually consists of the General Manager, the Editor in Chief and Deputy Managing Editor, and those who are deemed competent to be advisors to the editorial chart. The Editorial Board has the duty to provide input to the editorial staff in carrying out editorial work. The Editorial Board also resolves important editorial issues, for example involving news that is very sensitive or whether or not the news is made according to the agreed vision and mission of publishing.

4. Managing Editor

The editor of a press publication is usually more than one. Its main task is to do editing or editing, namely the activity of selecting and repairing the manuscript that will be published or broadcast. Internally, they are called Desk Editor, Field Editor, or Page Editor because they are fully responsible for the contents of certain rubrics and their editing. An editor usually handles one rubric, for example economic rubric, foreign affairs, sports.

5. Reporter

Under the editors are the reporters. They are soldiers in the editorial department. Looking for news and then making or compiling it, is the main task.

6. Photographer

Photographers (photo journalists or photographers) their job is to take pictures of certain events or objects that have news value or to complement news articles written by reporter. $\mathrm{He} / \mathrm{she}$ is a partner who is commensurate with the writing journalists (reporter). If the task of a journalist is to write a journalistic work in the form of a news article, opinion, or feature, then the photographer produces a Journalistic Photography (Photographic Communications). The photographer conveys information or messages through the pictures he takes. Journalistic photo functions include informing (to inform), convincing (to persuade), and entertaining (to entertain).

\section{Secretary}

Secretary has the responsibility in regulating the delegation of tasks that have been determined by the chief editor / executive editor, in addition to carrying out administrative tasks related to editorial operations. The editorial secretary is a supporting tool for the editorial staff in carrying out journalistic tasks and activities. 


\section{Business Department}

In charge of disseminating mass media, i.e. marketing or selling (mutual) mass media. This section is the commercial side including circulation / distribution, advertising, and promotion. Usually, the marketing department is led by a person. Company Leader or a Manager Marketing who leads the Circulation Manager, Advertisement Manager, and Promotion Manager.

Editorial management must be able to manage and direct all elements in it, including journalists to carry out their functions efficiently and effectively. Editorial management must focus on achieving the goals and objectives of the mass media organizations that have been set, including in carrying out the functions of planning, organizing, implementing and controlling as a business institution. Every individual who is incorporated in the editorial management must have a sense of belonging between one another because it involves the sustainability of the mass media. Every function and individual in a mass media organization must have a clear description of duties and responsibilities.

\section{Conclusion}

The work area of journalists in Medan is public space, an area that is worthy of being known by the public or the public. Therefore, journalists are required to have the ability to reveal and inform a complete problem by upholding the values of truth and justice and must be able to make themselves half diplomats, half detectives. This means that journalists must have skilled diplomacy skills, even though the way they work is similar to detectives. Mass media journalism is a tool used to convey messages from sources to the public using mechanical communication tools, such as newspapers, radio, television, films and so on. And in this case the mass media being referred to is print mass media. That newspapers are sheets published by the press which contain news, essays, writings, advertisements, and other journalistic products that are printed periodically, circulated, and sold in general, which function as social control tools that provide information both entertainment education and another thing for the community.

The print media organizational structure, the positions contained in the media editor can be described as follows: General Manager, Editor in Chief, Editorial Board, Managing Editor, Journalists, Photographers, Secretaries, and Business Departments.

\section{References}

Canggara, H. (2003). Dimensi Komunikasi. Jakarta. Rajagrafindo Persada.

Junaedhie, K. (2001). Ensklopedi Pers Indonesia. Jakarta. Gramedia Pustaka Utama.

Kovach \& Rosenstiel, T. (2003). Sembilan Elemen Jurnalisme. Jakarta. Pantau.

Kuswandi, W. (2002). Komunikasi Massa Sebuah Analisis Media Televisi. Jakarta. Rineka Cipta.

Meinanda, T. (2001). Komunikasi dan Jurnalistik. Bandung. Armico.

Mc.Quail, D. (1994). Teori Komunikasi Massa, Jakarta. Rajagrafindo Persada.

Muhtadi, A. (2003). Komunikasi Jurnalistik. Jakarta. Grassindo.

Saragih, M. Y. (2018). Some Characteristics of Islamic Journalism Based on Al Quran. Budapest International Research and Critics Institute Journal. Vol. 1 No.1, Pp. 1-10.

Yunus, S. (2010). Jurnalistik Terapan. Bogor. Ghalia Indonesia.

http://tonz94.wordpress.com/2009/05/02/mnajemen-media-massa 